\title{
Presidential Election and Portfolio Selections in the Nigeria Stock Exchange
}

\author{
Ifuero Osad Osamwonyi ${ }^{1}$ \& Osazee G. Omorokunwa ${ }^{1}$ \\ ${ }^{1}$ Department of Banking and Finance, University of Benin, Benin City, Nigeria \\ Correspondence: Ifuero Osad Osamwonyi Ph.D, Professor of Finance, Department of Banking and Finance, \\ University of Benin, Benin City, Nigeria.
}

Received: June 28, 2017

Accepted: July 26, 2017

Online Published: October 17, 2017

doi:10.5430/ijfr.v8n4p 184

URL: https://doi.org/10.5430/ijfr.v8n4p184

The funding for this study was provided by the University of Benin Research \& Publication Committee [URPC].

\begin{abstract}
This study seeks to investigate the effect of presidential elections on investors' portfolio selection in Nigeria from 2003 to 2011. The regression analysis was used to identify the effects that election could have on stock prices in the country, while event study was applied to investigate the focused effects of election event on portfolio selection in the Nigerian stock exchange. Price index for high and medium capitalization stocks were used in the analysis. The study showed that there were low returns performance in the stock market during elections and that elections events have strong (generally) negative effects on abnormal returns for the selected companies in the Nigerian Stock Exchange. In addition, the study showed a negative relationship between the return and risk behaviour of selected companies and election announcement in Nigeria. It is recommended that government and relevant authorities should increase the surveillance of both the market and political system prior to the presidential election in order to curtail the instability during this period.
\end{abstract}

Keywords: presidential election, portfolio selection, stock market, efficient market, Nigeria

\section{Introduction}

In every stock market, the investors have infinite set of securities or assets into which they can commit their hard earned fund so as to earn a return at a given level of risk. The term portfolio in finance refers to the collection of various assets that make up an investor's total investments. Portfolio selection comprises of the combination of various securities with unrelated variance in order for an investor to minimize risk and maximize securities returns. Typically, a rational investor constructs portfolio based on market fundamentals. But such decision could be affected by the outcome of presidential election.

Every four years in Nigeria, precisely before presidential elections, investors are usually faced with the outcome of the election in selecting their portfolios in the stock market. Stock market performance in election period is usually unpredictable. The uncertainty that surround the election process usually put market stakeholders (both locally and internationally) on a surveillance mood. This could affect the confidence of investors. Uncertainty leads to loss of confidence in the market by investors. And the average investor (individual or institutional) is assumed to be risk averse, such that excessive volatility and hence riskiness often erode investors' confidence. According to Osaze (2007), confidence is the foundation upon which the whole edifice of the financial market is built.

Political events most especially election in developing countries increase the level of uncertainty in the securities market. When the election win is widely expected, the financial markets will behave calmly in the year beforehand. Caldwell (2014) shows that British shares performed well in an election when opinion polls pointed to a heavy win for a particular party or candidate. In stark contrast, British shares do not react well when an election is difficult to call and the result goes right to the wire (Caldwell, 2014). The correlation certainly conforms to common sense as markets hate uncertainty, particularly when an election is too close to call. Whenever a country approaches election year, investors keep a close surveillance on events until the outcome of the event is final concluded.

But over the years certain share prices have been severely hit by the actions of elected leaders, some even by the mere mention of a new policy. The uncertainty that this creates unnerves investors, particularly in an election year. 
Investors hate uncertainty and would prefer it if there was a heavy favourite rather than a close race, which will potentially hold shares back until the electorate goes to the polls (Caldwell, 2014). This study seeks therefore to evaluate the return and risk of selected quoted companies on the Nigerian Stock Exchange before and after elections.

\section{Literature Review}

\subsection{Portfolio Theory}

The Modern Portfolio Theory (MPT) was developed by Harry Markowitz. Markowitz (1959) assumed that most investors want to be cautious when investing and that they want to take the smallest possible risk in order to obtain the highest possible return, optimizing return to the risk ratio. MPT states that it is not enough just to look at the expected risk and return of one particular stock. By investing in more than one stock, an investor can obtain the benefits of diversification, a reduction in the volatility of the whole portfolio (Markowitz, 1959). Modern portfolio theory also explains the selection and construction of asset portfolios based on the measured risk, risk preferences of individuals and the expected return on the investments. Investors will prefer to invest in a combination of securities which will assure better and more stable returns while minimizing risk. In building a portfolio of securities, a rational investor would only be interested in high returns with low risk (Osaze, 2000).

O'Neill (2000) states that MPT has important practical applications such as the reduction of volatility. The essence of MPT is to seek optimization of the relationship between risk and return by composing portfolios of assets determined by their returns, risks, and covariance or correlations with other assets. MPT develops a framework where, any expected return is composed of various future outcomes and are thereby risky, and this relationship between risk and return can be optimized through diversification (Markowitz, 1991). However, the risk and expected returns on a portfolio can be affected by announcement of relevant information.

\subsection{The Efficient Market Hypothesis and Event Study}

To understand the announcement effect, the paper considers the efficient market hypothesis (EMH), and consequently event study. EMH postulates that the market price for shares incorporates all the relevant information about those shares. This implies that the stock is correctly estimated until an imminent event alters that estimation (Lo, 2007). Lo (2007) asserts that the EMH's idea of informational efficiency has a counter-intuitive savour to it. This implies that the randomness of the changes in the series of prices produced by the market depend on the efficiency of the market. The more efficient the market, the more the price changes are completely unpredictable and random. The market is essentially information driven, thus unpredictable exogenous events such as: wars, weather, political shocks, insurgence, oil shocks, and political shocks can influence the outcome of investment. This outcome could be for a short or long term depending on the extent of the effect. Certain event such as election cycle has unique forces at play which are largely a product of history with little information value for current investment decisions. However, stock prices and returns are essentially driven by market fundamentals than by presidential elections (Jamshidloo, Madani \& Movahed, 2014).

Fama (1991) used 'event studies' to test for modification of prices to public news in place of semi-strong-form tests. Event studies provide the most focused evidence on efficiency because it allows for a close break between equilibrium-pricing and market efficiency issues with empirical evidence. MacKinlay (1997) observes that the importance of event study is that it is used to capture the rationality in the marketplace. The effect of an event on the value of a firm or an entity can be measured using financial market data. Since the effects of an event are immediately impounded in the security price, the measure of such event impact can be constructed using prices observed over specific period of time. The most efficient measure may require several days, weeks, months and years of observation.

\subsection{Information Asymmetry in Stock Market}

Mazol (2013) argues that the informational effect on decision maker and the operating of the stock market can be ascribed to assumption of heterogeneous expectations and assumption of homogeneous expectations. The assumption of heterogeneous expectations according to Mazol (2013) considerably alters the methods of measuring market equilibrium under condition of diverse news that sellers and buyers of securities possess. It is presumed that participants in the stock market evaluate probabilities of future conditions of the economy differently and, thus, have diverse estimates of expected returns in these conditions. Such differences are created by a variety of news that participants in the stock market possess, distinguish as accurate and alter their assessments on stock market processes on this basis. Thereby imposing the assumption of heterogeneous expectations on the participants in the stock market (Basak 2000). Akerlof (1970) proposes that in the financial market there exist an asymmetry of information about investment for the participants in the market. The core of this notion is for the justification of the stock market participant's investment decision. The stock market participants try to comprehend the signals in information about 
the external environment and the stock market in particular, through the signalling effect and signalling mechanism put in place to regulate their activities (Leland \& Pyle 1977).

For stock market participants, the most imperative signals emanate from different news item connected to imminent economic circumstances in the country. The theory of information asymmetry of stock market participants is centred on the postulation that participants in the stock market possess different information concerning the market on the trading activities, objects, as well as other basic information that may likely influence their actions and decisions in the market (Chae, 2005). The effect of announcement can be demonstrated by studying election activities in any country.

\subsection{Information around National Election in Nigeria}

The effect of election on the Nigeria economic through the stock market cannot be over emphasized. This could be traced to the development of media technology. The rumour about the candidate to be presented by the major political party, and region he is from could have dire consequences on the economy. Since the investor is particular about maximizing his /her wealth, political events ranging from selection of candidate and the outcome of the election could lead to market frictions. This can also affect the market microstructure, since all these are determine by information. Radner theory suggesting that "if economic decision makers have unlimited computational capacity for choice among strategies, then even in the face of uncertainty about the economic environment, an optimal allocation of resources based on competitive equilibrium can be achieved". According to Radner (1996), these uncertainties could lead to disequilibrium in the economy. Applying this concept to Nigeria situation in the face of ethnicity, religious differences and insurgence, political election will surely heat up the polity, thus affecting business activities.

Investors always strive to maximize their return and minimize losses. But most investor are more focused on the loss aversion and thereby losing big. This was address by Kahneman and Tversky (1979) using their Prospect Theory and later Cumulative Prospect Theory to analysis investor behaviour in terms of risk and return. The average Nigerian investors may be loss averse in nature and hence could be trapped by this. These could be linked to information asymmetry. The market friction caused by the outcome of political event in Nigeria has to do with differences in the information available to the politician and to the voters. The Nigerian capital market has its share of market frictions. This can increase the risk involved in doing business in Nigerian. Participant in the market can deviate from holding the market portfolio because of financial market frictions. Political or national election in Nigeria could worsen risk of investor thereby increasing risk when the outcome of the election is too close to call.

Degennaro and Robotti (2007) assert that financial market frictions create costs that restrict trades that rational individuals make (or would make in the absence of market frictions). In addition, these market frictions could also increase the counterparty cost in the Nigerian capital market. This in turn could affect the market microstructure. According to Asmar and Ahmad (2011), market microstructure influences transaction costs, market transparency, securities liquidity, market efficiency and securities values. Consequently, the central idea of the market microstructure theory is that the prices of securities need not completely reflect all available information because of a variety of frictions (Madhavan, 2000). Thus, market microstructure has an important effect on a financial market's efficiency and integrity (Baker \& Kiymaz, 2013).

\subsection{The Stock Market, Election Postponement and the Nigerian Economy}

The Nigeria 2015 general elections which was scheduled to hold on the 14th of February for Presidential and National Assembly elections, and 28th of February for State and House of Assembly elections were postponed to March 28 and April 11, 2015, respectively by the Independent National Electoral Commission (INEC). Market mood remained bearish. The NSE All-Share Index dropped by $-2.87 \%$ Week-to-date, while the market year to date performance dropped further to $-15.96 \%$ at the close of trading on February 10, 2015. This performance placed the Nigerian Stock Market as one of the worst performing market in the world in recent times. This in turn affected the foreign exchange market where the naira further depreciated against other currencies in all markets (as Nigeria currently has multiple rates). The postponements of the general elections affected market performance due to the level of uncertainties that surrounded the economy. In addition, the security situations in the country also increased the level of uncertainties in market and the economy in general.

\subsection{Empirical Analysis}

Boutchkova, Doshi, Durnev, and Molchanov, (2012) posit that empirical evidence about the impact of politics on stock markets is, however, generally diverse. Arin, Molchanov and Reich (2013) assert that the mixed and negligible evidence provided by the extant studies may be ascribed to two reasons: (i) the empirical models estimated by earlier 
study may have suffered from omitted variable bias as there is a good degree of model uncertainty regarding the selection of political variables; and (ii) anticipatory pricing in financial markets suggests that the political risk connected with election results is integrated into the prices of share long before the uncertainty is fully determined on election day.

Jamshidlooet.al (2014) investigate the performance of Iran`s Stock Market before and after election using trend and descriptive analysis. The finding in this study shows that in the year before and after election, there is a significant difference in performance in the stock market thus leading to market control. Angela and Wilson (2012) examine the stock market performance before and after general election in Nairobi using event study. The study shows that in short term, performance of securities market in Nairobi is influenced by political expectations and activities.

Ortega and Tornero (2009) examine the impact of political elections on the Spanish Stock Exchange using GARCH and event study. The result indicates that there is no evidence to empirically support the existence of political business cycles theory in Spanish stock market. Arin et al. (2007) examine response of stock market to political events applying Bayesian techniques to a new data set of political variables for 17 democracies. The findings show that there exists a weak relationship between the levels of stock returns and political variables. And that the number of political variables significantly affects stock market volatility. Thus investigating the effect of election on portfolio selection can be very revealing.

\section{Methodology}

The effect of election announcements information on the stock prices of selected companies is measured using event study methods. The selection of companies in the analysis is based on large cap and mid-cap companies in the Nigerian Stock Market. The companies selected for the study are then used to form two portfolios of assets which are incorporated in the analysis. The two sets of portfolios are derived based on the highest capitalization and mid-capitalisation. The active stocks in the market are ranked in terms of their capitalization and the top 10th percentile and the mid-10th percentile is selected. The basic method used for fitting models of normal stock return behaviour as a function of general market performance is the Ordinary Least Squares of regression analysis. The market model is built on the capital assets pricing model (CAPM), the most extensively used technique to estimate the returns on a firm's stock (Bosch \& Hirchey, 1989; Hovav \& D'Arcy, 2003; and MacKinlay, 1997). The simple CAPM is given as:

$$
R_{i t}=\alpha_{i}+\beta_{i m} R_{m t}+\varepsilon_{i t}
$$

Where:

$R_{i l}=$ realized return for the $\mathrm{i}^{\text {th }}$ stock in the time period $\mathrm{t}$,

$R_{m t}=$ realized return for the market index in time period t. Here the ASI is used, and

$\alpha_{\mathrm{i},} \beta_{\mathrm{i}}=$ regression coefficients.

The estimation of each portfolio of a sample of 80 daily returns is done using the market model. The estimation period begins with 100 days before election announcement date and 21 days before the election announcement date to end it (or day $t=-100$ to day $t=-21$ ). The interval of the valuation period applied in this study is in line with prior studies of capital market responses (Bosch \&Hirchey, 1989; Hovav\&D'Arcy, 2003). The study focuses on five separate events for a- 21 day period around the event announcement (i.e. -10 days to +10 days) as proposed by Cheng and Leung (2006). These five event periods are:

(1) Ten trading days prior to the information announcement, $t-10$, to one day prior to the date of announcement day (i.e. day $\mathrm{t}=-10$ to $\mathrm{t}=-1$ );

(2) Announcement day, $t=0$, to ten trading days after the announcement, $t+10$; (i.e. day $t=0$ to $t=+10$ );

(3) Two trading days after the announcement, $t+2$, to ten trading days after the announcement, $t+10$; (i.e. day $t=$ +2 to $\mathrm{t}=+10)$,

(4) Ten trading days prior to the information announcement, $t-10$, to ten days after the date of announcement day $t$ +10 (i.e. day $\mathrm{t}=-10$ to $\mathrm{t}=+10$ ); and

(5) Five trading days prior to the information announcement, $t-5$, to five days after the date of announcement day $t$ +5 (i.e. day $t=-5$ to $t=+5$ ). The splitting of events into the five windows is allowed for more robust investigation of the election event on stock for the three portfolios. Since Presidential elections in Nigeria are normally held on weekends, event day $\mathrm{t}=0$ is taken as the Friday before Election Day and Monday after Election Day. 
The estimation of coefficients from equation (3.1) is applied to the five event periods to predict normal returns: $(+2$, $+10),(0,+1),(-5,+5),(-10,+10)$, and $(-10,-1)$.

Deviations of realization returns from normal returns (that is, prediction errors during the event periods), are estimates of abnormal returns (AR). Consequently, the market model is applied to compute the abnormal return (prediction error) for the equity stock of a portfolio $i$ on event day $\mathrm{t}$, as under:

$$
A R_{i t}=R_{i t}-\left(\hat{\alpha}_{i}-\hat{\beta}_{i} R_{m t}\right)
$$

The sample average of market model cumulative abnormal return is equal to zero for any given event period is the null hypothesis tested. More formally, for a sample of $\mathrm{N}$ securities, the samples mean abnormal returns on any given day $t$ is:

$$
\overline{A R}_{t}=\frac{1}{N} \sum_{i=1}^{N} A R_{i t}
$$

To accurately measure the abnormal returns using the market model over a holding period or specific time period, the sample mean prediction errors are summed to derive the sample mean cumulative abnormal returns as:

$$
\overline{C A R}_{t}=\sum_{i=T_{1}}^{T_{2}} A R_{t}
$$

Where; $T_{1}$ and $T_{2}$ represent the starting and ending days of sample-specific event periods within the overall 21 days $t$ $=-10$ to $\mathrm{t}=+10$ event period. The $\mathrm{t}$-statistic test for the significance of PE is computed as:

$$
t-\operatorname{statistic}(\text { for } A R)=\frac{\overline{A R}_{t}}{\hat{S}\left(\overline{A R}_{t}\right)}
$$

Where $\hat{S}\left(\overline{A R}_{t}\right)=\sqrt{\sum_{i=T_{1}}^{T_{2}} A R_{t} \frac{\left(\overline{A R}_{t}-\overline{\overline{A R}}_{t}\right)^{2}}{179}}$ and

$$
\overline{\overline{P E}}=\frac{1}{180} \sum_{t=-200}^{t=-21} A R_{t}
$$

where $\mathrm{t}=-200$ to $\mathrm{t}=-21$ is the 180 days estimation period. Under the null hypothesis of no abnormal returns, the $\overline{C A R}$ is assumed to be unit normal and both serially and cross sectionally independent. The interval test statistic for each sample and each holding period of $\mathrm{T}$ days in length is assumed to be approximately unit-normal and can be written as under and follows a t-statistic distribution:

$$
t-\operatorname{statistic}(\text { for } C A R)=\frac{\overline{C A R}_{t}}{\hat{S}\left(\overline{A R}_{t}\right) \sqrt{T_{2}-T_{1}+1}}
$$

In order to obtain more robust results, the significance of daily average abnormal returns is further tested using a nonparametric binominal statistic calculated as under:

$$
Z=\frac{A-E}{\sqrt{N P(1-P)}}
$$

Where:

$\mathrm{A}$ is the actual number of positive prediction errors, $\mathrm{E}$ is the expected number of positive errors (i.e. equal to $\mathrm{N} \times \mathrm{P}$ ), $\mathrm{N}$ is the number of observations, and $\mathrm{P}$ is the expected percentage of positive prediction errors. Under the null hypothesis of no effect, $\mathrm{P}=0.5$. This binomial statistic is more conservative than the $\mathrm{t}$-statistic test and does not require the assumption of normality.

Moreover, in creating asset portfolio returns, the following formula is used: 


$$
\text { Portfolio return }=\sum_{i=1}^{n} \frac{\text { price of stock } i}{\text { sum of stock prices in portfolio }} \times \text { return on stock } i
$$

The study will test the hypothesis that "there is no significant relationship between the return and risk behaviour of selected quoted companies in the Nigerian Stock Exchange and presidential election announcements in Nigerian".

\section{Data Analysis}

\section{Election Announcement and Returns-Risk Behaviour of Individual Companies}

In this section, we consider the effects of election on individual stock returns in the market using an event study mechanism. The procedure for the event study follows the general procedure for evaluating event study.

\subsection{The Returns Estimations}

The result of the initial estimation of the market model for the stocks is reported in Table 1 below. In the result, the average estimates of the alphas and betas are shown for all of the companies within the portfolios. For the high capitalization stocks, the coefficient of alpha is positive on average with a value of 0.64 while that of beta is also positive but lower at 0.26 . For the medium capitalization stocks, the average values of alpha and beta are almost similar. Similarly, $r$ is the correlation coefficient between the daily rates of returns security $\left(R_{t}\right)$ and the daily rates of returns on the market portfolio $\left(\mathrm{R}_{\mathrm{m}}\right)$. The table indicates that there are rather low degrees of relationships between the market and daily returns on individual securities; the mean value of the $r$ is 0.11 for high cap stocks and 0.19 for low cap stock.

Table 1. Estimates of the $\alpha$ 's and $\beta$ 's for each of the firms

\begin{tabular}{ccccc}
\hline & \multicolumn{2}{c}{ High cap } & \multicolumn{2}{c}{ Mid cap } \\
\cline { 2 - 5 } & Mean & st. dev. & Mean & st. dev. \\
\hline A & 0.64 & 0.35 & 0.43 & 0.39 \\
\hline B & 0.26 & 0.28 & 0.41 & 0.01 \\
\hline R & 0.11 & & 0.19
\end{tabular}

Source: Author's compilation from regression estimates, April 2016

\subsection{Market Reactions Estimates}

Using the results of the estimated normal returns model obtained in Table 1, the abnormal returns on each of the stocks during the estimation periods are obtained. The outcome for the abnormal return for each stock price for 10 days before and 10 days after the presidential elections are presented in the charts that follow. From the trends presented (in charts) for both assets, the initial patterns of the return movements during the period are highlighted. The result for 2003 shows marked changes in abnormal returns across the two periods. Most of the abnormal returns were negative for the entire ten days for which the abnormal returns where obtained. Only few days ( 8 and 7 days before elections) had actual and meaningful positive average returns. This result suggests that abnormal returns tended to perform poorly during presidential election in 2003. 


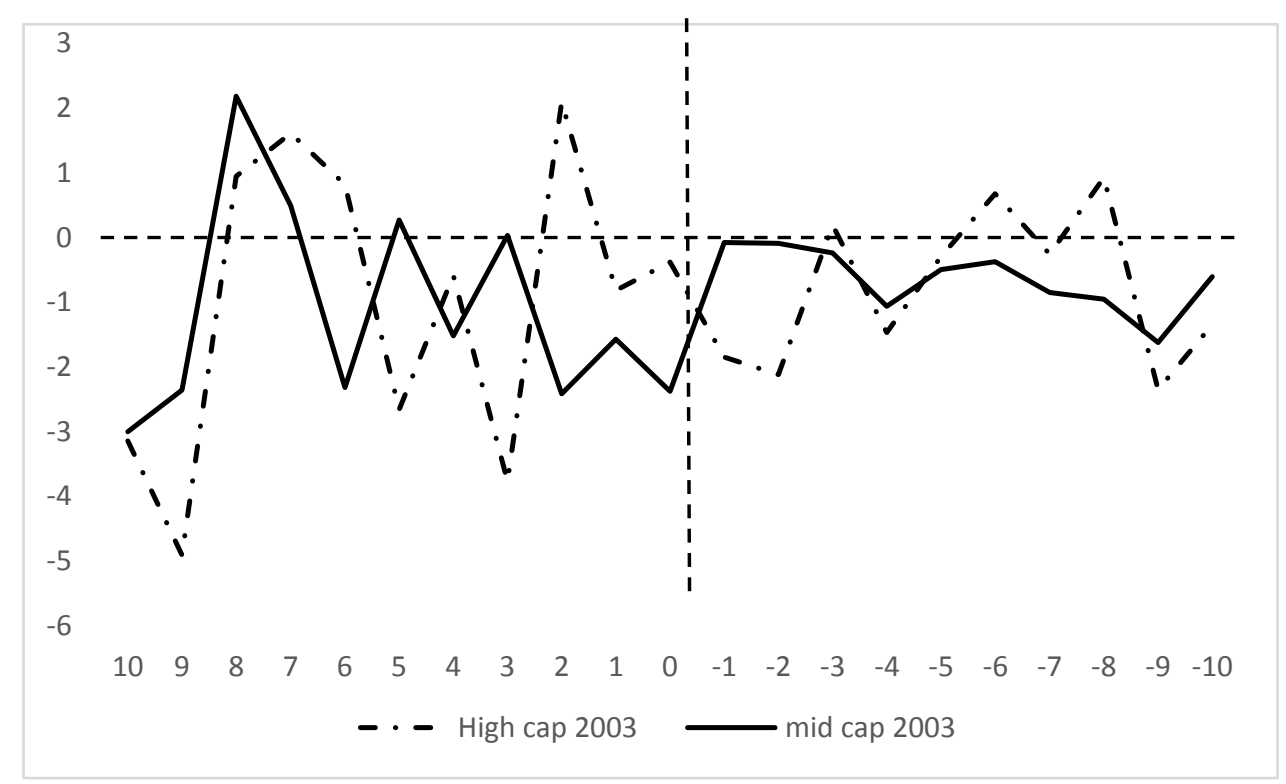

Figure 1. Chart for abnormal returns for the portfolios (2003)

The results for 2007 are reported in Figure 2. In the chart, the abnormal returns for high cap stock were positive throughout the pre-election period but dropped after the election. For the mid cap returns, there was a lot of vacillations between positive and negative abnormal returns. This shows that abnormal returns were quite different between the two portfolios during the election period in 2007.

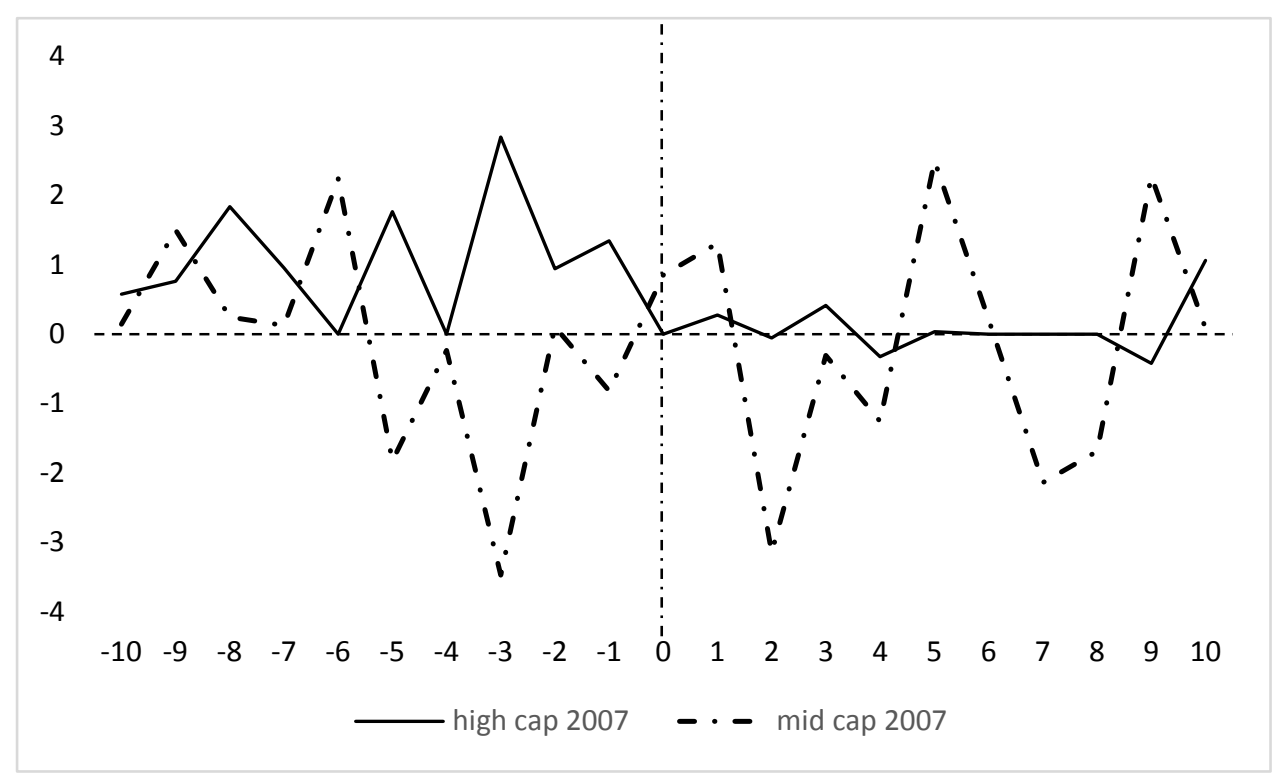

Figure 2. Chart for abnormal returns for the portfolios (2007)

For the 2011 period, there were certain similarities between high cap and mid cap abnormal results for the period and the abnormal returns appeared to be more positive during the period before the Election Day. Moreover, the volatility of the abnormal returns was actually higher after the elections than before the elections. 


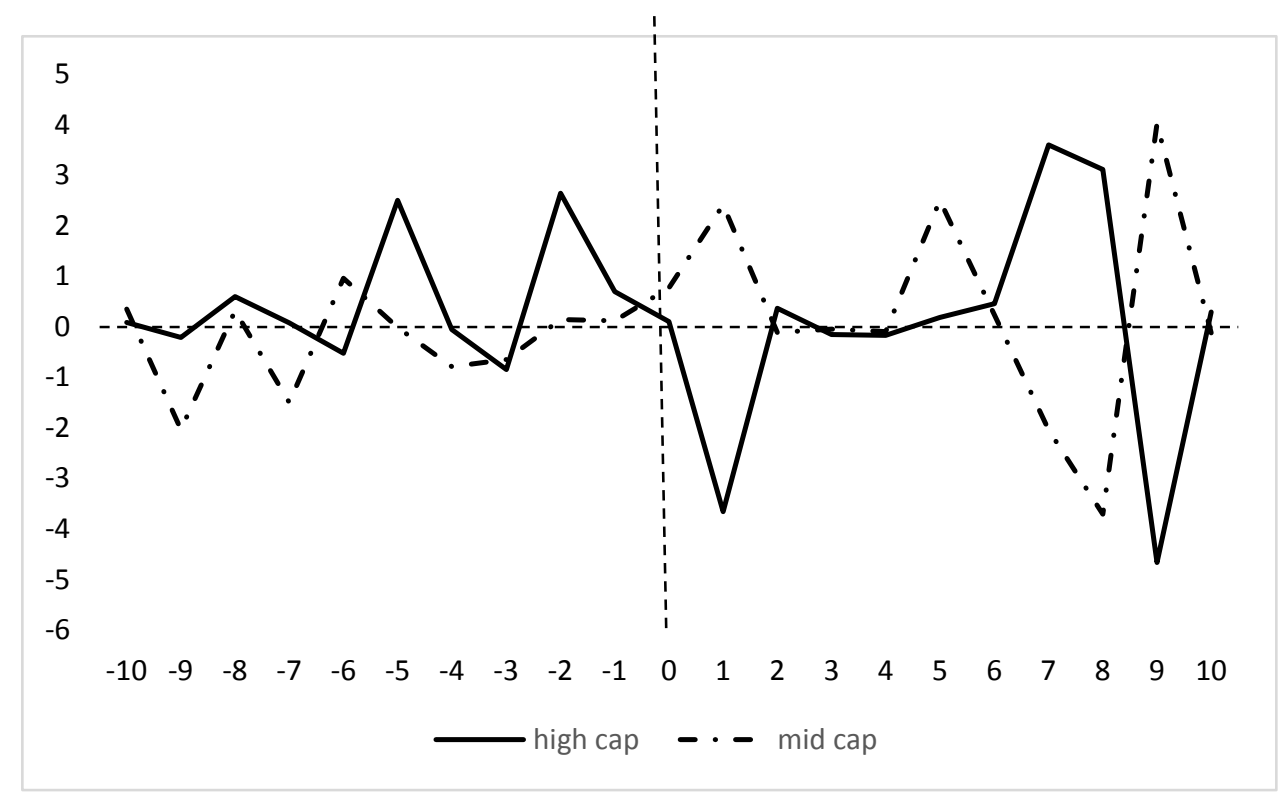

Figure 3. Chart for abnormal returns for the portfolios (2011)

Further to the analysis of the abnormal returns in the election years, we consider the values also by grouping them into high cap and mid cap. The result for the abnormal returns for high cap is shown in Figure 4. In the chart, there were more movements before the election than after the election. Moreover, the high cap stock abnormal returns were more negative in pre-election 2003 than any other period.

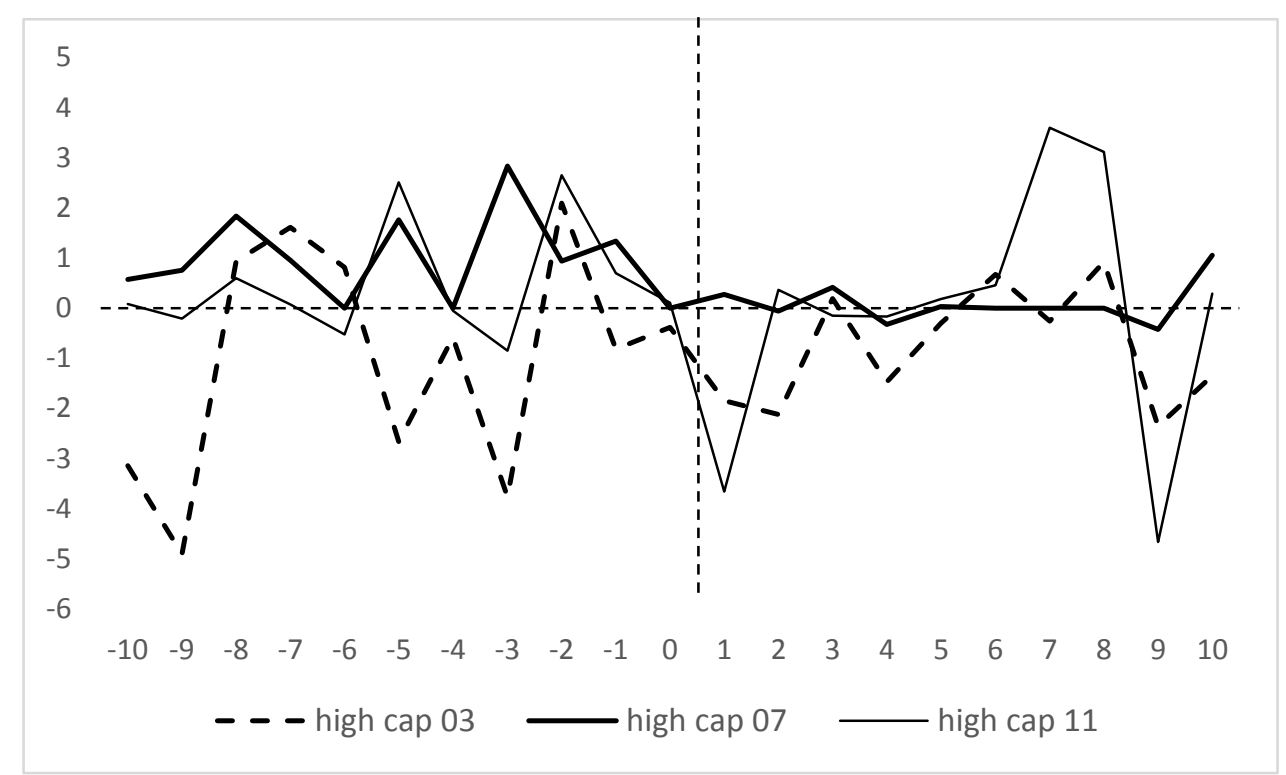

Figure 4. Abnormal returns based on high cap stocks

Finally, the abnormal returns for mid cap stocks are shown in Figure 5. From the chart, it can be seen that changes in abnormal returns were more frequent before the election in each of the years but the changes became deeper (but less frequent) after the elections. 


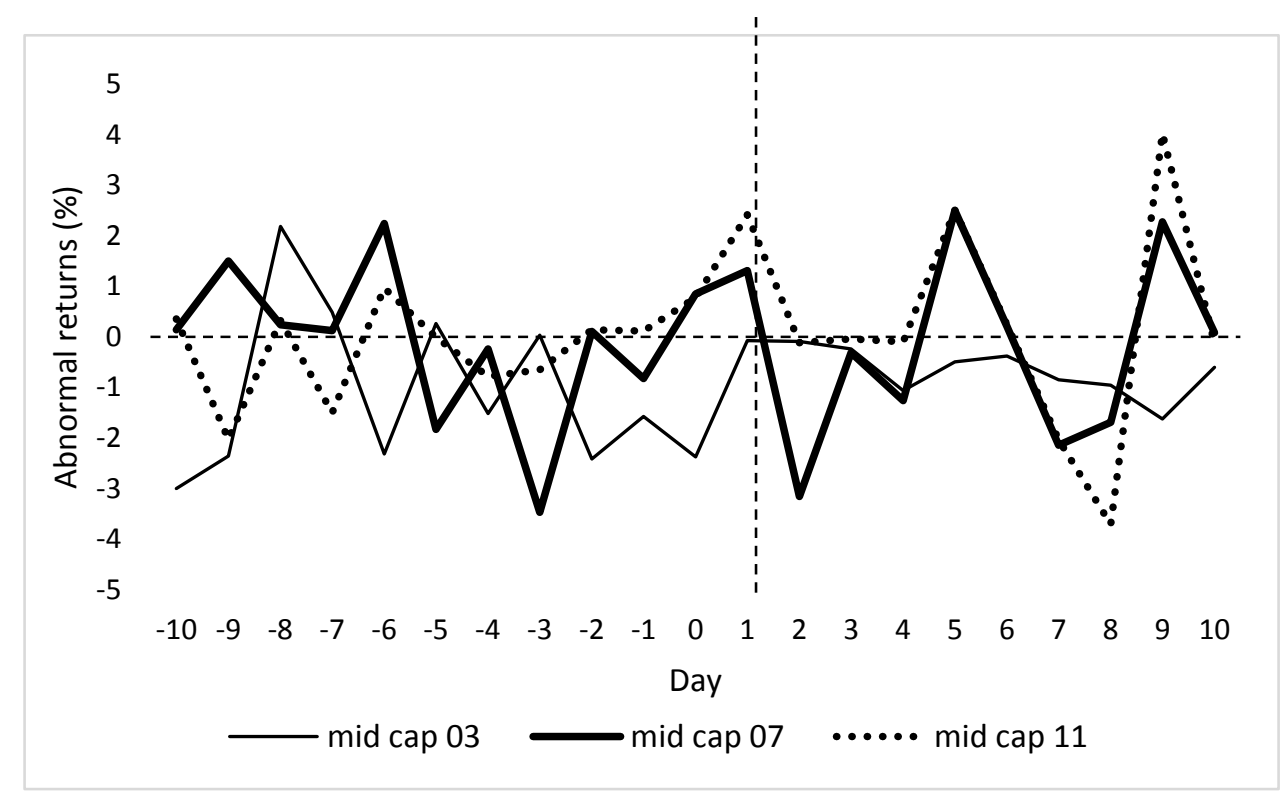

Figure 5. Abnormal returns based on low cap stocks

The average abnormal returns (AAR) for the combined sample and for the combined election periods on high and mid cap portfolios are shown in Table 2. Two days before the elections, average abnormal returns for high cap stocks were positive while it became negative two days after the elections. For the mid-cap stocks, there were a lot of negative AARs around the days close to the election day. Only the day after elections had positive AAR for the mid-cap stocks around the days close to elections. Apparently, the average return for mid-cap stocks for the period was negative. This gives indication that returns on mid-cap stocks tended to generally fall following the announcement and conduct of elections for the entire sample period. Moreover, emphasis is laid on the significance of the average abnormal returns for each of the assets. The t-values for the AAR for both portfolios are significant at the 1 percent level. Thus suggests that the general negative AAR observed for the entire period in both high and mid cap assets is actually significant.

Table 2. Summary of daily average abnormal returns

\begin{tabular}{ccc}
\hline Day & & Company \\
\hline-10 & High cap & Mid cap \\
-9 & -0.83 & -0.84 \\
-8 & -1.45 & -0.96 \\
-7 & 1.13 & 0.91 \\
-6 & 0.88 & -0.29 \\
-5 & 0.10 & 0.30 \\
-4 & 0.54 & -0.52 \\
-3 & -0.21 & -0.85 \\
-2 & -0.59 & -1.36 \\
-1 & 1.89 & -0.72 \\
0 & 0.41 & -0.76 \\
+1 & -0.09 & -0.25 \\
+2 & -1.74 & 1.21 \\
+3 & -0.60 & -1.12 \\
+4 & 0.15 & -0.20 \\
+5 & -0.65 & -0.81 \\
+6 & -0.03 & 1.50 \\
& 0.38 & 0.02
\end{tabular}




\begin{tabular}{ccc}
+7 & 1.12 & -1.68 \\
+8 & 1.35 & -2.12 \\
+9 & -2.48 & 1.56 \\
+10 & 0 & -0.21 \\
\hline -value & $-4.46[\mathrm{p}=0.01]$ & $-6.09[\mathrm{p}=0]$ \\
Percentage positive abnormal returns & 55.0 & 43.3 \\
$z$-value & -6.73 & -7.52 \\
\hline
\end{tabular}

Source: Author's compilation from regression estimates, April 2016

Thus, the effect of elections on returns for individual asset group can be said to be negative. The next step of this analysis is to conduct the empirical test on the cumulative abnormal returns for the event periods in order to observe whether a significant difference exists in its pattern over the event. In this regard, the cumulative abnormal returns are computed for the two portfolios in the study in order to present a more robust contemporaneous analysis. The critical evaluation of the (presidential election) event study is demonstrated by the CAR for each of the portfolio under study. In Table 3, the results of the calculated average and cumulative abnormal return for the event window are reported. The distribution of cumulative abnormal returns for the pre-election period $(-10,-1)$, the announcement period $(0,+1)$ and the post announcement period $(+2,+10)$ are shown in the table. The table also reports the distribution of cumulative abnormal returns with overlapping election periods of different length such as $(-10,+10)$ and $(-5,+5)$. Thus, the cumulative returns are reported for the window periods which show before the elections, after the elections, as well as over the elections. This gives us the idea regarding the sources of any significant changes in the cumulative abnormal returns that might have occurred during the estimation window.

From the table, it can be seen that negative CARs for before the elections are higher than those for after the elections both for high and mid cap stocks. The values for CAR for $(-10,-1)$ are -1.04 for high cap and -1.02 for mid cap; and when compared with CAR values for $(+2,+10)-0.67$ and -0.69 for the respective portfolios, it shows that pre-election CARs were more severe (negative) than post-election CARs. This apparently presents indications that the build-up to elections generates more agitations on the stock market which lead to poor performance of stock returns, irrespective of the categories of the stocks. These results are more forceful when the significance of the CARs are considered. Indeed, each of the CAR estimates in the table has significant $t$-values at the 5 percent level.

The CAR values for the election period were also high for both portfolio types. The values for the $(0,+1)$ period was -1.11 for high cap and -1.22 for mid cap. These suggest that a very sharp drop in stock returns occurred on average within the period of the elections. The coefficients for the CARs are also significant at the 5 percent level.

Table 3. Cumulative average prediction errors

\begin{tabular}{|c|c|c|c|c|}
\hline \multirow{2}{*}{ Period } & \multicolumn{2}{|c|}{ High cap } & \multicolumn{2}{|c|}{ Mod cap } \\
\hline & CAR & t-value & CAR & t-value \\
\hline Pre $\quad(-10,-1)$ & -1.04 & $-2.57 *$ & -1.02 & -7.03 \\
\hline During $(0,+1)$ & -1.11 & -2.26 & -1.22 & -0.71 \\
\hline Post $\quad(+2,+10)$ & -0.67 & -2.88 & -0.69 & -3.94 \\
\hline $\operatorname{Across}(-10,+10)$ & -0.89 & -4.46 & -0.90 & -7.52 \\
\hline Across $(-5,+5)$ & -1.06 & -3.95 & -0.87 & -4.80 \\
\hline
\end{tabular}

Source: Author's compilation from regression estimates, April 2016

The test of the hypothesis that, "There is no significant relationship between the return and risk behaviour of selected quoted companies in the Nigerian Stock Exchange and presidential election announcements in Nigerian" is based on the analysis done so far. A number of outputs were obtained from the event study and there is need to combine the outputs into a direct outcome that can help in the hypothesis testing. In the event study, the general outcome is that there is generally low returns performance in the stock market during elections and that election events have strong (generally) negative effects on abnormal returns for the selected companies in the Nigerian Stock Exchange. The null hypothesis is thus rejected in this section since the statistical tests have confirmed that a negative 
relationship actually exists between the return and risk behaviour of selected companies and election announcement in Nigeria.

\section{Conclusion}

This study focuses on the impact of presidential announcement / information effect on the individual investor's portfolio selection. Event study and regression analysis were used to empirically test the hypotheses of this study. The essence of this study was to investigate the extent to which information impact on the efficiency of the stock market and assess the theory of political business cycle in Nigeria. The results also suggested that individual companies in the market were generally affected by presidential elections in Nigeria. The effect was shown to be negative and implies that stock prices for individual companies tend to generally fall during election periods. Trading activities in the market appears to slow down when elections are being held in the country.

Essentially therefore, the findings of this study effectively locate the place of presidential elections in stock market dynamics in the country. In particular, the debate on the extent to which politics can and should affect the market has been enhanced from this study in Nigeria.

\section{References}

Akerlof, G. (1970). The market for lemons: Quality, uncertainty and the market mechanism. Quarterly Journal of Economics, 84, 488-500. https://doi.org/10.2307/1879431

Angela, K., \& Wilson, N. (2012). Stock market performance before and after general election.International Journal of Academic Research in Business and Social Sciences, 2(9).

Arin, K. P., Molchanov, A., \& Reich, O. F. (2013). Politics, stock markets and model uncertainty. Empirical Economics, 45(1), 23-38. https://doi.org/10.1007/s00181-012-0601-5

Asmar, M., \& Ahmad Z. (2011). Market microstructure: The components of black-box. International Journal of Economics and Finance, 3(1), 1-52. https://doi.org/10.5539/ijef.v3n1p152

Baker, H.K., \& Kiymaz, H. (2013, August 29,). Trends in market microstructure. Retrieve from http://www.europeanfinancialreview.com

Basak, S. (2000). A model of dynamic equilibrium asset pricing with heterogeneous beliefs and extraneous beliefs. Journal of Economic Dynamics and Control, 24, 63-95. https://doi.org/10.1016/S0165-1889(98)00064-5

Bosch, J., \& Hirschey, M. (1989). The valuation effects of corporate name changes. Financial Management, 18(4), 64-73. https://doi.org/10.2307/3665798

Boutchkova, M., Doshi, H., Durnev, A., \& Molchanov, A (2012). Precarious politics and return volatility. The Review of Financial Studies, 25(4), 1111-1154. https://doi.org/10.1093/rfs/hhr100

Caldwell, K. (2014). 1966 - 2010: How stock markets perform before general elections. The daily telegraph, Saturday 18 , October.

Chae, J. (2005). Timing information, information asymmetry, and trading volume. Journal of Finance, 60, 413-442. https://doi.org/10.1111/j.1540-6261.2005.00734.x

Cheng, L.T.W., \& Leung, T.Y. (2006). Revisiting the corroboration effects of earnings and dividend announcements. Accounting and Finance, 46(2), 221-241. https://doi.org/10.1111/j.1467-629X.2006.00164.x

DeGennaro, R. P., \& Robotti, C. (2007). Financial market frictions. Economic Review, Federal Bank of Atlanta, 92(3), 1-16.

Fama, E. F. (1991). Efficient capital markets. The Journal of Finance, 46(5), 1575-1617. https://doi.org/10.1111/j.1540-6261.1991.tb04636.x

Hovav, A., \& D'Arcy, J. (2003).The impact of denial-of -service attack announcements on the market value of firms. Risk Management and Insurance Review, 6(2), 97-121. https://doi.org/10.1046/J.1098-1616.2003.026.x

Jamshidloo, R., Madani, S.M.M., \& Movahed, M. S. (2014). Performance of Iran`s Stock Market before and after election. SCRO Research Annual Report, 2, 91-95.

Kahneman, D., \& Tversky, A. (1979). Prospect theory: An analysis of decision under risk. Econometrica, 263-291. https://doi.org/10.2307/1914185

Leland, H., \& Pyle, D. (1977).Informational asymmetries, financial structure, and financial intermediation. Journal of Finance, 32, 371-387. https://doi.org/10.2307/2326770 
Lo, A.W. (2007). Efficient markets hypothesis. In Blume, L., \& Durlauf, S. (Eds.), The new Palgrave: a dictionary of economics ( $2^{\text {nd }}$ ed.), Palgrave Macmillan Limited. Retrieve from http://ssrn.com/abstract=991509

MacKinlay, A. C. (1997). Event studies in economics and finance. Journal of Economic Literature, 35(1), 133-139.

Madhavan, A. (2000). Market microstructure: A survey. Journal of Financial Markets, 3(3), 205-258. https://doi.org/10.1016/S1386-4181(00)00007-0

Markowitz, H. M. (1959). Portfolio selection: efficient diversification of investments. New York: John Wiley \& Sons.

Markowitz, H. M. (1991). Foundations of portfolio theory. The Journal of Finance, 46(2), 469-477. https://doi.org/10.1111/j.1540-6261.1991.tb02669.x

Mazol, A. (2013). The Influence of election cycles on stock market fluctuations in developing countries. A thesis submitted in partial fulfilment of the requirements for the degree of Kyiv School of Economics.

O'Neill, W. (2000). Fundamentals of the stock market. Blacklick, OH, USA: McGraw-Hill Professional Book Group.

Ortega, D.F., \& Tornero, A.P. (2009). Politics and elections at the Spanish Stock Exchange. 9th Global Conference on Business \& Economics, October 16-17, Cambridge University, UK.

Osaze, B.E. (2000). Nigerian capital market in the African and global financial system, Nigeria: Bofic Consulting Group Ltd.

Radner, R. (1996). Bounded rationality, indeterminacy, and the theory of the firm. The Economic Journal, 106(438), 1360-1373. https://doi.org/10.2307/2235528 